\title{
HERO AND FATE IN THE NIBELUNGENLIED
}

\author{
Asia A. Sarakaeva (a), Elina A. Sarakaeva (b) \\ (a) Hainan University. Haikou, China. Email: 1977487 837[at]qq.com \\ (b) Hainan College of Economics and Business. Haikou, China. Email: 2689655 292[at]qq.com
}

\begin{abstract}
Based on the material of the epic poem "Das Nibelungenlied" (The Lay of the Nibelungs) the article discusses the concepts of hero, heroism and fate which existed in the minds of medieval Europeans. This paper explores the relationship between these concepts. The authors postulate and prove the hypothesis that, in the framework of mentality under study, the measure of higher heroism was foresight and active acceptance of one's fate. Fate, in turn, was revealed only to those heroes who were able to doom both themselves and the maximum number of other people to death. The authors show that Fate in the "Lay of the Nibelungs" is a constant, albeit secret, participant of the events; it interacts in complex ways with other participants. Fate directs the actions of the characters and is itself directed by them, revealing itself only to selected brave ones, to those who will be able to become its co-author, who, in accordance with its plans, will boldly go to death and lead others there too. Only such people can be considered heroes.
\end{abstract}

\section{Keywords}

Das Nibelungenlied (The Lay of the Nibelungs); Mentality; Medieval Society; Germanic Peoples; Heroism; Hero; Fate

This work is licensed under a Creative Commons «Attribution» 4.0 International License. 


\title{
ГЕРОЙ И СУДЬБА В «ПЕСНИ О НИБЕЛУНГАХ»
}

\section{Саракаева Ася Алиевна (a), Саракаева Элина Алиевна (b)}

(a) Хайнаньский государственный университет. Хайкоу, КНР. Email: 1977487 837[at]qq.com

(b) Хайнаньский институт экономики и бизнеса. Хайкоу, КНР. Email: 2689655 292[at]qq.com

\begin{abstract}
Аннотация
В статье на материале эпической поэмы «Песнь о нибелунгах» рассматриваются понятия героя, героизма и судьбы, бытовавшие в сознании средневековых европейцев, изучаются взаимосвязи между этими понятиями. Авторы постулируют и доказывают гипотезу, что в рамках исследуемого менталитета мерилом высшего героизма было предвидение и активное принятие своей судьбы. Судьба же, в свою очередь, открывалась лишь тем героям, которые способны обречь на гибель и себя, и максимальное число других людей. Авторы доказывают, что судьба в «Песни о нибелунгах»- постоянный, хотя и тайный участник событий, в сложном взаимодействии с другими участниками. Она направляет поступки персонажей и сама направляется ими, открывая себя лишь избранным храбрецам, тем, кто сумеет стать ее соавтором, кто, в соответствии с ее предначертаниями, смело пойдет к смерти и поведет туда же других. Только такие люди могут считаться героями.
\end{abstract}

\section{Ключевые слова}

Песнь о нибелунгах; Менталитет; Средневековое общество; Германские народы; Героизм; Герой; Судьба

Это произведение доступно по лицензии Creative Commons «Attribution» («Атрибуция») 4.0 Всемирная 
Fate, luck, destiny are the most important concepts of medieval Germanic legends and literature. The feeling of the inevitability of fate pervades the Icelandic sagas and "Elder Edda", as well as the greatest literary work of the German High Middle Ages: the epic poem "Das Nibelungenlied" (The Lay of the Nibelungs). From the very first lines, introducing his main characters into the narrative the author of the poem already announces their death and the cause of this death. The same predictions of future - especially misfortunes - are scattered throughout the text of the poem. Of course, the anonymous author of the 13th century was not the creator of the plot he expounded, his contemporaries were very well familiar with the plot: who would kill whom and what the consequences would be. Therefore, departing from the linearity in the narration, the author could not be afraid that he would spoil his intrigue for his readers or listeners. Nevertheless, such constant running ahead and referring to future calamities and disasters leaves the reader with the impression that all the events described are very much predetermined, subordinated to a single narrative flow, which is the sum of the individual wills and choices of the characters, but at the same time entails them and does not allow any alternatives or options.

The aim of this work is to clarify the role and functions of fate in the "Lay of the Nibelungs", the nature of its manifestations in life and actions of the characters, the premises that shape fate, the interdependence between the concepts of fate and heroism. How did the author of the poem, his characters and his audience understand heroism? Who can be called a hero, and on what basis? What is fate in the mentality of medieval Germans, and how does it interact with the hero's own will? To whom and why is fate revealed? In the framework of this article, we intend to answer these questions to achieve the stated goal.

An important place allotted to fate has long been noticed by German scholars. At the early stage of the scientific comprehension of the poem, the commentators like Schroeder, Verber, and Volk, who thought in the framework of the Christian paradigm of guilt and atonement, argued that the heroes' own crimes became their evil doom: each of them should die in atonement for the murder committed before (Anderson, 1987, p. 165). However, the researcher Thomas Anderson, who worked in the middle of the 20th century, disagrees with them. He explains:

"A historical reading of the sources rather suggests that they (characters of the poem.-A.S.) are heroes who have fallen into the traditional impasse of heroic deeds. They must die because this is the general law of heroic literature, but they surpass their fate by demonstrating personal qualities" (ibid.). 
Such an interpretation becomes the leading one at the present stage of the study of the poem: heroes die not because they made certain mistakes, but simply because they are heroes.

Thus, the authors of the monograph "Medieval German Literature" note that the events of the poem only seem to be varied, but in fact, there are no alternative options of the plot development (Gibbs, 1997, pp. 213214). On the one hand, on the outside, the heroes are free to make decisions; neither other people's will nor even circumstances press on them. On the other hand, their social status, their own characters, as well as the position and characters of other actors with whom they interact simply do not allow them to act in any other way, not in the way they act in the poem. Everything happens as it should happen, in accordance with the statement that the poet makes in the first adventure and repeats in the last - that all joy eventually turns into grief.

A renowned modern Nibelungen scholar Jan-Dirk Müller in his famous monograph "The rules of the Endgame" draws attention to hints or omens scattered throughout the text of the tragic fate of the heroes. For example, in an episode when the Burgundians travel to the feast to Etzel where they all have to die, they stop to stay in the castle of their friend Margrave Rüdiger. Rüdiger and his wife Gotelinda give them gifts, and the head of the Burgundian expedition Hagen von Tronje rejects the gift chosen for him and instead asks for and receives a shield that previously belonged to the murdered relative of Gotelinda. At the same time the famous sword Balmung which he took from Siegfried after he killed him hangs on his hip. Thus, now Hagen is fully armed with the weapons of the dead. The property of the dead, the scholar comments, is intended for those who are doomed to die (Mueller, 2007, p. 122).

$\mathrm{H}$. Homan, in the article specially devoted to the study (and denouncing) of the image of Hagen Tronje, claims that this character not so much subjects to fate or accepts it - the moment he has learnt his own fate and that of his comrades, he becomes the active co-acter of the fate (Homan, 1982, pp. 764-765). This statement is based in particular on the episode when the Burgundians cross the Danube. On the way to Hungary they stop to rest near the Danube, and Hagen explores the river shore in search of a cross-over. He spots mermaids bathing in the river and steals their clothes to get them to reveal the future to him. The mermaids say that all of the Burgundiantrain is going to be slaughtered by the Huns of Etzel. Then Hagen meets the ferryman and requires him to ferry the Burgundians to the other side of the Danube. When the ferryman refuses, Hagen kills him. However, to his kings and comrades he tells nothing 
about these events, he doesn't disclose to them the prophecy of the mermaids, and lies directly when asked whether he has caused any harm to the ferryman. Homan thus explains the hero's reticence: Hagen deceives the rulers with the sole purpose that the journey should continue. Thus, he robs them of the last opportunity to determine their own fates, and pushes them on the path predicted by the mermaids. According to the researcher, this behavior contrasts sharply with all that this hero was doing before. Before meeting the mermaids Hagen struggled hard to provide the Burgundians' survival - he tried to dissuade them from going to Etzel, he forced them to bring along their entire armed squad. However, after this meeting, his motivation is changed to the opposite one, because the contact with the Otherworld transformed him. From now on his loyalty is not absolute; it is given to a higher purpose, namely the implementation of the predicted fate (ibid.).

The problems of hero and fate relations in the world outlook of ancient and medieval German peoples are most thoroughly examined in the works of the outstanding Russian cultural scholar A. Gurevich. He notes two points that are fundamentally important for our topic. Firstly, the Scandinavian traditions are characterized by a pronounced emphasis on the heroic death of the character. Thus, commenting on the representation of the historical past in the "Circle of the Earth" by Snorri Sturluson, Gurevich concludes:

"Not so much their deeds and exploits as the circumstances of the death of each king are at the center of the narration - obviously, the meeting of the king with his personal fate and his death attracted primary interest of Snorri and his audience" (1994, p. 149).

The second conclusion of A. Gurevich seems to us the most significant, and fully applicable not only to the Scandinavian sagas, but also to our own material - the German Lay of the Nibelungs. The scholar emphatically repeats his favorite statement that the German heroes feel neither humility nor resentment of fate, they do not obey it and do not oppose it - they accept it courageously and initiatively, go towards it and implement it through their own deeds. In the traditions of the Germans

“... there is not a hint of a passive perception of fate, of submission to it or humility before a higher power. On the contrary, knowledge or a premonition of one's own destiny encourages an individual with the highest energy and honor to fulfill what is required, not trying to evade it, but courageously accepting it" (1994, p. 152).

Moreover, the hero is at least a co-author of his own destiny, or, as the Eddic Song of Atli says about a female avenger, "she grows her own 
fate" (ibid., 154). "The heroes themselves, their will and heroic ethos are the source of decisions that are "solidified" into fate," Gurevich summarizes in one of his other works (Gurevich, 2005, p. 52).

So, all commentators agree on the main point: the German heroes cannot but perish; this is the culmination and proof of their heroism. By and large, a hero for German legends is not so much a person who has accomplished a feat as a person who was beautifully killed and beautifully avenged. What matters is not the fact of the violent death itself, but how the character was able to meet it, how many enemies they managed to take with them, and most importantly - whether they went to death without fear, whether they managed to evade the ending by fate.

In connection with that, it is not surprising that in German medieval literature the motive of foreboding or predicting the fate of a hero is so frequent. For example, the title hero of "Beowulf" fought for many years in many battles and was always confident of his own abilities, and only before the last battle with the dragon, did he feel a sense of impending doom. Although the poem does not describe any prophecies or bad signs, the inner feeling of the approaching end is enough to make king Beowulf, before going to the dragon's cave, say goodbye to his retinue, to make him remember and list all the main milestones of his life (Tikhomirova, 1975, pp. 139-143).

In "Elder Edda", forebodings or predictions are so frequent that it makes no sense to even list them. We mention only those that relate to the plot of Sigurd and the sons of Gyuki. The song "Prophecy of Gripir" tells how the young man Sigurd comes to the wise seer Gripir to ask about his future. In response to his inquiries, Gripir describes him in detail all that will happen to him: revenging his relatives, killing a dragon, freeing and deceiving Brunhild, marrying Gudrun and twinning with her brothers Gunnar and Hogni, and finally, death at the hands of the latter. Apparently, the saddest news for Sigurd is that he will break the oaths made to Brunhild and offend her by deceitfully marrying her to another person. Nevertheless, the hero does not make a single attempt to somehow change the future, to avoid, if not death, then at least the breach of oath. Instead, he thanks Gripir for the prophecy: "Fare thee well! One cannot argue with fate!" (Elder Edda. 1975, p. 274) and sets off to meet the predicted fate.

In "The Lay of Sigurd", unfortunate predictions begin to haunt the sons of Gyuki immediately after the murder of Sigurd: a raven and an eagle promise them death at the hands of the king of Hunns, Brunhild prophesies to her husband Gunnar that he will fall into the hands of enemies alive [6, 289]. In the "Greenland speeches of Atli", when Gunnar and 
Hogni are going to King Atli's feast, their wives try to dissuade them all night, and then throughout the entire journey their relatives try to convince them not to go to the enemy's house, but the heroes remain completely deaf to all warnings (Elder Edda. 1975, pp. 318-319).

We believe that this plot move - the prophecy about death, which the hero ignores - was not accidentally introduced into all of these and in a great many other narratives, and not even to enhance the tragic sound of the legend. The real goal is to emphasize the character's courage, their willingness to go towards death, not blindly, but with their eyes wide open. The fact is that the "heroic ethos" is a rather limited ethical system; in fact, it emphasizes only two moral qualities: courage and loyalty to one's blood or political clan. But these two qualities, especially courage, must be present in the actions of any hero in an extreme degree; in order to be worthy of being called a hero, a person must consciously seek death, even if he was warned in advance about it, and even if it is not necessary.

However, in the multilayered "Lay of the Nibelungs" compiled at a higher level of civilizational development, marked by the depth of psychological depiction of the characters, the interaction of the characters and their fate is no longer so straightforward.

Unlike his Eddic counterpart, Siegfried of the "Lay" has no idea what awaits him. However, the vast majority of the characters share his ignorance, and only two people discover their future fate. Characteristically, these are the main characters of the Lay, the mortal enemies: Krimhild and Hagen.

The very first Adventure of the poem speaks of the prophetic dream of the young Princess Krimhild, in which she had a beloved falcon, but two eagles torn him to pieces before her eyes. The girl asks her mother, the wise Queen Ute, to explain this dream to her, and receives a definite answer: the falcon means her future spouse, and the eagles - the enemies who would kill him. Upon learning that she is facing early widowhood, Krimhild declares that she will not marry at all, not to experience grief from the loss of her beloved (Lay of the Nibelungs, 1975, pp. 360-361). However, when Siegfried arrives in Worms, Krimhild falls in love with him and marries him, not only showing no previous determination to remain celibate, but even not worrying about Siegfried and his impending death. She remains amazingly careless until the death of her husband, first provoking his conflict with her relatives, and then trustingly revealing Siegfried's vulnerability to the most dangerous and cruel of these relatives. It seems that she simply forgot about her prophetic dream.

Hagen accepts the sentence of the fate in a completely different manner. Having learned from the conversation with the mermaids about the 
upcoming extermination of all the Burgundians, he first of all checks how reliable the source of information is. According to the mermaids, one of his companions must still survive, and this is the royal chaplain. Then Hagen arranges a test of the prophecy: in the middle of the Rhine he throws the priest out of the boat and tries to drown him. The priest, however, does not sink; he gets out on the shore and goes back to Worms. The prophecy thus verified, Hagen believes that the mermaids did not lie to him (Lay of the Nibelungs, 1975, pp. 537). From now on, all his actions proceed from the belief that he and his kings are going to die, and all that can and should be done under the circumstances is to accept death with as much dignity as possible. He aims at showing to the enemies no mercy, giving friends no false hopes of salvation at the cost of loss of honor, and leaving to the observers not a shadow of doubt in the unshakable courage of Burgundians. Interestingly, he persistently hides the prophecy of the mermaids from all his companions, making no exceptions for his feudal lord King Gunther, nor for his brother Dankwart, nor for his best friend, Volker the fiddler.

First of all, we note that the very choice of the people who received the prophecy is strange: an experienced politician and a young girl. Why did fate want to be open to them?

Our hypothesis is that knowing one's future is a kind of seal certifying an individual's status as a true hero. By the time the prophecy was received, Hagen had already accomplished many feats. Some of them are only mentioned or referred to as past events: for example, the fight against Walter in the battle of Waskenstein (ibid., p. 624), others - participation in the war against the Saxons and Danes and in quest for Brunhild's hand, the murder of the invincible Siegfried - unfold before the eyes of the reader. Thus, Hagen's courage and loyalty is undeniable and repeatedly proven, and in order to be considered an epic hero, he needs only one final touch, a kind of final exam - he must learn in advance about his death and properly use this knowledge. Hagen passes this exam during the crossing of the Danube and in the halls of King Etzel. In addition, Hagen von Tronje is genetically connected with the underworld; he, as we have fully proved in one of our previous articles (Sarakaeva, Lebedeva 2018, 32), is a half-elf by birth and a Nibelung by right of possession of the Nibelung treasure. Approaching the border between the world of the living and the world of the dead, he can already hear voices from the darkness.

It would be very tempting to use the same fact, i.e. possession of the treasure, to explain why Krimhild was chosen as well. After all, she, too, was the owner of the treasures of the dead, and thus, she was involved 
with the Otherworld. However, we have to reject such an explanation. First, Krimhild had a prophetic dream much earlier than she touched the treasure. Secondly, as we have said above, Siegfried, who has obtained the treasure of Nibelungs with his own hands, does not know anything about his future, nor has he any forebodings; he does not see any prophetic dreams. It remains to be assumed that Krimhild and Hagen, in addition to treasure and consanguinity, are united by some other common feature, and it is this feature that gives the two of them the right to read the dictates of fate.

We dare to hypothesize that this common feature is the ability and desire to organize a massive bloody massacre. Early medieval Germans were literally bewitched by heroic death, not without reason only those who fell in battle were honored with a joyful post-death existence in Valhalla. Therefore, it is logical that the leaders, whose will pushed hundreds of other people to this noble death, should have occupied a special place in the collective imagination of the Germanic peoples.

Siegfried acts as a lone warrior. The author of the poem is so little interested in Siegfried's main feat, the killing of the dragon, that he doesn't not even want to devote a separate chapter to it, but simply describes this event in retrospect, in a short retelling of Hagen (Song of the Nibelungs 1975, 370). With all the strength and boldness of the Netherland prince, his main role in the poem is not proactive, but casual, he doesn't perform significant actions himself, but rather determines the significant actions of other characters. And, most importantly, he does not have time, before his death, to show any resistance to his killer, not to mention taking more enemies with him to the next world. Because of this, he does not reach a true heroic level, and the future is not revealed to him.

Krimhild and Hagen are different. Their actions are proactive, their will is directed to death, and they confidently impose it on the maximum number of other people. This longing for Valhalla has long remained hidden even from them. Throughout the first part of the poem, Krimhild wants only family happiness; Hagen, until his departure from Worms, dissuades Gunther and his brothers from suicidal decisions, trying to provide them and himself with maximum safety. However, when the previous desires of the characters turn out to be impracticable, when the world refuses them happiness and safety, the heroic vector of their will immanent to their spirit is actualized, the vector that is directed towards death. These two people have the right to a special relationship with fate, because they are ready to accept it and act as its co-authors, taking hordes of people with them to the grave so that the memory of their death will be preserved for centuries. 
However, there is no complete equality between the main characters of the "Lay of the Nibelungs" in terms of their relation to fate. Hagen actively seeks an answer to a question about the future and receives the necessary information in reality, in contact with the inhabitants of the Otherworld, who prophesy to him his own death, along with his whole house. Though he keeps the prediction in secret, he directly meets the predicted, subordinates all his actions to this secret knowledge and uses it for its intended purpose, that is, in order to meet the enemies fully armed and inflict the maximum damage before the predicted comes true. Krimhild does not make any efforts to find out the future, this knowledge is literally imposed on her in a dream. Having learned her fate, she makes a short-term attempt to evade the predicted fate, but later ignores the meaning of the prophecy.

And this establishes a certain hierarchy between them: Hagen's heroism is mature, intellectually sober, originated from his own heroic exploits; Krimhild's heroism is instinctive and emotional. He is a man, a legitimate citizen of the world of heroes, in everything, even in the pursuit of death, remaining faithful to his clan. She is a woman, an involuntary and uninvited guest in the heroic world, who usurped male privileges and, for the sake of her revenge, distorted all human relations, arbitrarily placing her love for her first husband above her duty to her second husband, to her brothers and sons. Krimhild's heroism is undeniable, but at the same time flawed. And therefore, having received secret knowledge given to her as a hero by fate, she does not really know how to handle it.

Another aspect of Krimhild's prophetic dream worth considering is the content of the dream. Interestingly, this dream does not concern her fate, but only the death of her first husband. Meanwhile, she herself will have to die by sword, which, in itself, is much more surprising and unlikely than the same death of the warrior Siegfried. Why doesn't she dream about her tragic end? Does she herself and her death have no independent significance, and everything that happens to her after Siegfried counts no longer? But such an assumption directly contradicts the plot in which the role of Krimhild as an active participant and organizer of the impending catastrophe is predominantly realized in the second part of the poem. Hagen, however, learns of his own death, which, however, is bound to general extermination of all the Nibelungs. Unlike Gunnar in "Elder Edda" to whom his wife predicts that he will be captured and chained (Elder Edda, 1975, p. 289), Hagen from the "Lay" is informed only that he and all his friends will be killed by Etzel's vassals. Mermaids do not detail what will happen to the hero himself, they do not talk about his future captivity and death at the hands of a woman (Korneeva, 1975, p. 533). 
We assume that such a difference in the content of the prophecies is rooted in the difference in the functions of the heroes. Hagen is a heroprotector, not without reason his lyrical characteristic in the poem is "the shield of the Nibelungs", and even his name can be etymologized as "protect, guard, defense" (Sarakaeva, Sarakaeva \& Lebedeva, 2016). Throughout the poem, his main activity is precisely to protect the royal house of Burgundy from foreigners, dishonoring rumors, dynastic crises and other possible dangers. Therefore, the information about the future that he is allowed to know relates specifically to the death of the royal house, and his own death is listed only among all the others. Krimhild is the avenger heroine. She does not protect anyone, she doesn't conquer lands or foes, and her heroism is revealed only in a situation of revenge and applies only to this situation. And therefore, she is given a prophecy about the death of her husband, for whom she will have to avenge. Her own death no longer belongs to the high space of heroism, and, like all events of the profane world, is not worth mentioning in the prophecy.

Fate in the "Lay of the Nibelungs" is a constant, albeit secret, participant of the events; it interacts in complex ways with other participants. Fate directs the actions of the characters and is itself directed by them, revealing itself only to selected brave ones, to those who will be able to become its co-author, who, in accordance with its plans, will boldly go to death and lead others there too. Only such people can be considered heroes. Nevertheless, even these chosen ones do not live their entire life in maximum tension; they do not constantly direct their will to death and fulfillment of duty, so fate reveals to them only certain aspects of future tragedies.

\section{References}

Anderson, T. (1987). Preface to the Nibelungenlied. Stanford: Stanford University Press.

Elder Edda (1975). In Beowulf. Elder Edda.Song of the Nibelungs (pp. 181-356). Moscow: Fiction. (in Russian)

Gibbs, M. \& Johnson, S.M. (1997). Medieval German Literature. NY: Routledge.

Gurevich, A.Ya. (1994). The dialectic of fate among the Germans and the ancient Scandinavians. In The concept of fate in the context of different cultures (pp. 148-158). Moscow: Science. (in Russian)

Gurevich, A.Ya. (2005). The individual and society in the medieval West. Moscow: ROSSPEN. (in Russian)

Homan, H. (1982) The Hagen Figure in the Nibelungenlied: Know him by his Lies. ML,N 97(3), 759-769. DOI: 10.2307/2 906222

Korneeva, Yu. (Trans.) (1975). The Lay of the Nibelungs. In Beowulf. Elder Edda. Song of the Nibelungs (pp. 357-628). Moscow: Fiction. (in Russian) 
Mueller, J. D. (2007). Rules for the Endgame. The World of the Nibelungenlied. Baltimore, Maryland: TheJohnHopkinsUniversityPress.

Sarakaeva, A.A. \& Lebedeva, I.V. (2018). The value of the treasure (Horde) in the medieval Germanic epic "Song of the Nibelungs. In Modern research in the field of linguistics, literature and culture.Collection of scientific papers on the materials of the I International scientific-practical conference. May 31, 2018 (pp. 26-36). Nizhny Novgorod: NOO "Professional Science". (in Russian)

Sarakaeva, A.A., Sarakaeva E.A. \& Lebedeva I.V. (2016). Hagen from Tronje: the origin of the legend. In Collection of scientific papers on the materials of the I International scientific-practical conference "Word and text in the light of modern studies of philological sciences", April 30, 2016 (pp. 65-77). Nizhny Novgorod: NOO "Professional Science". (in Russian)

Tikhomirova, V. (Trans.) (1975). Beowulf. In Beowulf. Elder Edda. Song of the Nibelungs (pp. 27-180). Moscow: Fiction. (in Russian)

\section{Список литературы}

Anderson, T. (1987). Preface to the Nibelungenlied. Stanford: Stanford University Press.

Gibbs, M. \& Johnson, S.M. (1997). Medieval German Literature. NY: Routledge.

Homan, H. (1982) The Hagen Figure in the Nibelungenlied: Know him by his Lies. $M L, N$ 97(3), 759-769. DOI: 10.2307/2 906222

Mueller, J. D. (2007). Rules for the Endgame. The World of the Nibelungenlied. Baltimore, Maryland: TheJohnHopkinsUniversityPress.

Гуревич, А.Я. (1994). Диалектика судьбы у германцев и древних скандинавов. В Понятие судьбы в контексте разных культур (стр. 148-158). М.: Наука.

Гуревич, А.Я. (2005). Индивид и социум на средневековом Западе. М: РОССПЭН.

Корнеева, Ю. (Пер.) (1975). Песнь о нибелунгах. В Беовуль о нибелунгах (стр. 357-628). М.: Художественная литература

Саракаева, А.А. \& Лебедева, И.В. (2018). Значение сокровища (Horde) в средневековом германском эпосе «Песнь о нибелунгах». В Современные исследования в области лингвистики, литературы и культуры. Сборник научных трудов по материалам I Международной научно-практической конференции. 31 мая 2018г. (стр. 26-36). Нижний Новгород: Профессиональная наука.

Саракаева, А.А., Саракаева, Э.А. \& Лебедева, И.В. (2016). Хаген из Тронье: происхождение легенды. В Сборник научных трудов по материалам I Международной научно-практической конференции "Слово и текст в свете современных исследований филологических наук", 30 апреля 2016 года (стр. 65-77). Нижний Новгород: НОО "Профессиональная наука".

Старшая Эдда (1975). В Беовульф. Старшая Эдда. Песнь о нибелунгах (стр. 181356). М.: Художественная литература

Тихомирова, В. (Пер.) (1975). Беовульф. В Беовульф. Старшая Эдда. Песнь о нибелунгах (стр. 27-180). М.: Художественная литература. 